\title{
The role of long term care centers in the Polish system of mental health care
}

\author{
Rola zakładu opiekuńczo - leczniczego w polskim systemie \\ psychiatrycznej opieki zdrowotnej.
}

\section{Krzysztof Siejko ${ }^{1}$ AEF, Aneta Tylec ${ }^{2}$ AEF, Halina Dubas-Ślemp ${ }^{2}$ E, Piotr Książek ${ }^{1}$ A, Bartłomiej Drop ${ }^{3}$ A, Artur Kochański ${ }^{4}$ ABCDE, Katarzyna Kucharska ${ }^{5}$ AEF}

\author{
${ }^{1}$ Chair and Department of Public Health, Medical University of Lublin \\ ${ }^{2}$ II Department of Psychiatry and Psychiatry Rehabilitation, Medical University of Lublin \\ ${ }^{3}$ Department of Information Technology and Medical Statistics, Medical University of Lublin \\ ${ }^{4}$ Association of Mental Health Protection in Lublin \\ ${ }^{5}$ Department of Neuroses, Personality Disorders, and Eating Disorders, \\ Institute of Psychiatry and Neurology in Warsaw
}

\begin{abstract}
Objective: The aim of this work is to review the role of mental health care center and treatment center specialized in psychiatry in the Polish system of mental health care as a whole.

Review: For many years in Poland, the process of transformation of psychiatric care model from the institutional (inpatient setting, most expensive) to community care model (personalized, much cheaper), has been taking place. The effective - coordinated system of community care should significantly improve cooperation in the treatment, while the community forms of health care should ensure full availability, complexity, and continuity of care provision. In many cases, the community support is inadequate and cannot provide patient with care at his home environment. For mentally ill, there may be a need for the use of the long term health care centers specialized in psychiatry.

Conclusions: A long term mental health care center specialised in mental health plays an important role in long-term care for the mentally ill. As far as a mental health service user's perspective is concerned, the continuity of care and treatment in the long term health care center (as a health care unit) appears to be more useful and satisfying compared to a residential home for people with chronic mental illnesses. There is a need for broad discussion on the special place of the long term health care center specialized in psychiatry in the present Polish system of mental health care and on the improving of care pathways between inpatient-, day careand, community care package.
\end{abstract}

Keywords: mental health care center, system of mental health care, community care system

\section{Streszczenie}

Cel: Celem niniejszej pracy jest omówienie roli zakładu opiekuńczo-leczniczego o profilu psychiatrycznym w polskim systemie psychiatrycznej opieki zdrowotnej.

Poglądy: Od wielu lat w Polsce zachodzi proces transformacji modelu opieki psychiatrycznej z systemu instytucjonalnego (szpitalnego, najkosztowniejszego) do modelu opieki środowiskowej (spersonalizowanego, tańszego). Efektywny - skoordynowany system opieki środowiskowej powinien poprawiać współpracę w leczeniu, a środowiskowe formy leczenia mają zapewnić pełną dostępność, ciągłość i kompleksowość opieki. W wielu przypadkach wsparcie środowiskowe jest niewystarczające i nie ma możliwości zapewnienia pacjentowi opieki w warunkach domowych. Istnieje wtedy konieczność korzystania z opieki stacjonarnej, długoterminowej - psychiatrycznego zakładu opiekuńczo-leczniczego.

Wnioski: Zakład opiekuńczo-leczniczy o profilu psychiatrycznym, choć nie jest placówką środowiskową i dotyczy marginalnej części pacjentów, zajmuje ważne miejsce w polskim systemie psychiatrycznej opieki zdrowotnej. Z perspektywy osoby z zaburzeniem psychicznym korzystniejsza jest kontynuacja leczenia w warunkach zakładu opiekuńczo-leczniczego o profilu psychiatrycznym (jednostka ochrony zdrowia) niż w domu pomocy społecznej dla przewlekle psychicznie chorych. 
Istnieje potrzeba szerokiej dyskusji nad miejscem psychiatrycznego zakładu opiekuńczo-leczniczego w modelu systemu opieki środowiskowej oraz wypracowania funkcjonalnej integracji pomiędzy poszczególnymi ogniwami leczenia ambulatoryjnego, środowiskowego i stacjonarnego.

Słowa kluczowe: psychiatryczny zakład opiekuńczo-leczniczy, system psychiatrycznej opieki zdrowotnej, system opieki środowiskowej

\section{Introduction}

In Poland, as in other European countries, a constant increase has been observed in the number of health services provided in the area of psychiatric care and addiction treatment. One indicates a two-fold increase of medical advice given in the outpatient healthcare and an increase by $50 \%$ in the stationary care (hospital care) [1]. It is connected, inter alia, with the arrival of new civilization challenges: cultural, social and economic transformations and the risk of marginalization that accompanies them, the use of psychoactive substances, ageing population and migration. Mental disorders constitute to pose a significant medical and social problem. They lead to discrimination or social exclusion of people affected by them. Mental illnesses are ranked as the 4th on the list of reasons of disability in the Polish society [2]. For many years, the only source of data on the distribution of mental disorders across Poland were the statistics prepared by the Institute of Psychiatry and Neurology in Warsaw. In 2012, the first, three-year epidemiological study was carried out that concerned the distribution of mental illnesses and availability of psychiatric healthcare. It was conducted in accordance with the methodology of the World Health Organization in cooperation with the World Mental Health Consortium. The Epidemiology of Psychiatric Disorders (EPD) research showed that $23.4 \%$ of the Polish population at least once in their lifetime experienced a single mental disorder. In this group, every fourth person experienced more than disorder, and every twenty-fifth - three or more mental disorders [3].

\section{The Polish system of psychiatric care - historical background}

The process of transformation of the model of psychiatric care from the institutional system (hospitalbased and the most costly) to the community-based model (personalized and cheaper) has been lasting in Poland for a number of years. It was as early as in the first half of the 20th century that the first inspirations of the discussed reform appeared. In 1950s, the transformation of psychiatric care was additionally enhanced by the advancement in the area of pharmacovigilance of mental disorders (introduction and dissemination of new, efficient neuroleptics and antidepressants). In 1970s in Lesser Poland the first solutions aimed at community-based care (home-based treatment) were used. In the years 1970 - 1995, positive changes took place that enhanced the transformation process. The number of psychiatric beds decreased and the following numbers increased: of psychiatric wards in general hospitals and beds for psychiatric patients; of psychiatric hospitals (the new and smaller facilities were opened) thus increasing their availability; and lastly, of clinics and day wards. It was then that the first complexes of community-based treatment were founded. In 1980s, due to the limitation of the number of hospital beds and growing demand for psychiatric health services, the adverse phenomena exacerbated: re-hospitalization (the system of "revolving door"), prolonging of stays in psychiatric hospitals because of social reasons and referring patients to nursing homes (both, their number and standard were insufficient) [4]. The legislative amendments introduced in 1990s (the Act on Protection of Mental Health, the Act on Social Assistance, to mention the most significant ones) left the door open for the changes in the system of care of people suffering from mental disorders. In 2010 the Council of Ministers adopted the National Program of Mental Health Protection which assumed the direction of the development of psychiatric care system and addiction treatment to be focused on the development of various forms of communitybased care [5]. The basic psychiatric care is supposed to be provided by the centers of mental health $(\mathrm{CMH})$ consisting of four subunits - the complex of: outpatient clinics (mental health clinic), community-based treatment, daily wards and hospital treatment.

\section{The Polish system of psychiatric care - dynamics of changes}

A lot of people with mental disorders do not use healthcare and does not have an opportunity to make use of it. It is estimated that in Poland, about $25 \%$ of people in need benefit from psychiatric care [6], whereas the population of at least $33-50 \%$ of people with depressive syndrome or an addiction, and $80 \%$ of people with dementia syndrome or schizophrenia ,should be provided with this type of care [7].

Figure 1. The scheme of the Polish system of psychiatric care.

A mentally disordered person, independently or with family support, can and should function in home environment, at the same time being embraced by the community-based forms of treatment and social support. An efficient, coordinated system of community-based care shall considerably improve cooperation in treatment and community-based forms of treatment (mental health clinic, 
Figure 1. Diagram of the Polish system of mental health care.

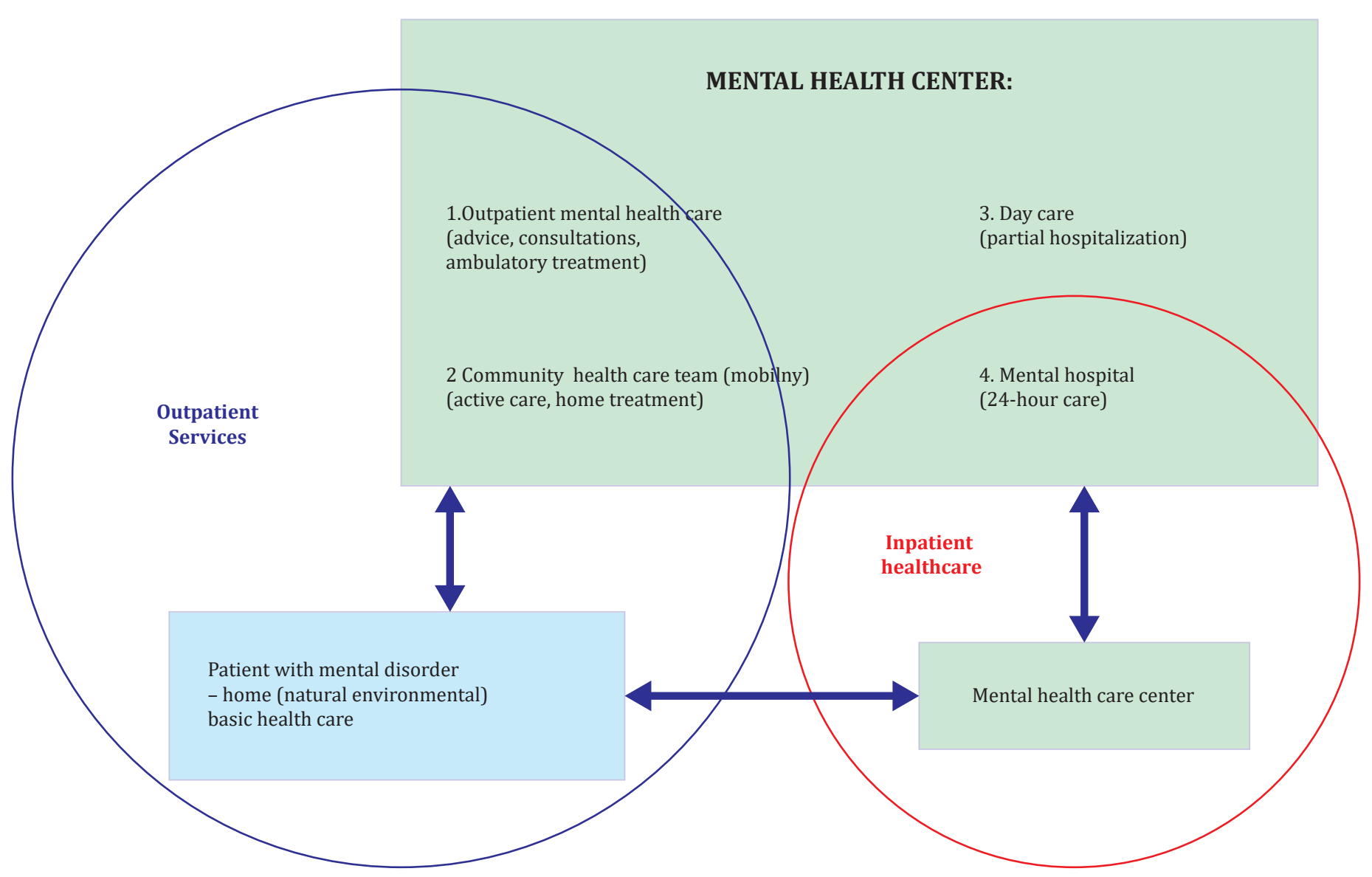

community-based treatment complexes, day ward and hostel for people suffering from mental disorders) are to ensure full availability, continuity and complexity of care. The number of mentally disordered people using outpatient care has increased by 150,000 individuals (increase by $14 \%$ ) in the last four years. The biggest increase was noted in the community-based care (community-based treatment complexes) where the total number of treated patients has increased three-fold (from 9,600 to 29,800). A mental health clinic is still the most common form of psychiatric outpatient care available in 93\% of counties all over Poland. In 2011, 68 community-based treatment complexes were functioning, mainly in the large urban centers. Treatment at the daily psychiatric ward offers a chance to avoid hospitalization or, alternatively, constitutes its supplementation. When it comes to the daily psychiatric care in Poland, 16,000 people were treated in 2014 ( $9 \%$ more than in 2011) [8]. A hostel, carrying out the tailored psychotherapeutic and rehabilitation programs in the environment of the sheltered, close to home-like accommodation, remains the least available form of psychiatric care in Poland. In 2011, on the territory of seven provinces. there were 19 hostels operating, that admitted 649 people (mostly addicts) [9].
Sometimes treatment in the outpatient conditions is very difficult, or even impossible, for example due to the degree of disease symptoms intensity, especially in the cases of aggression, auto-aggression or because of the lack of the patient's and/or his/her family's cooperation in the therapeutic process. Patient may then be subjected to psychiatric hospitalization (upon his/her own consent, in an emergency mode or the one applied for pursuant to article 22, 23 and 29 of the Act on Mental Health Protection) [10]. Hospitalization, for various reasons (therapeutic ones - not long stay outside home environment, economic ones - the most expensive form of treatment), shall be as short as possible. In 2015, there were 48 psychiatric hospitals (in 2014 - 49) which had the total of 17,800 beds $(0.2 \%$ more than in 2014). As many as 200,800 patients stayed in them $(0.4 \%$ more than in 2014). The patient's average length of stay at a psychiatric hospital equaled 30.1 days (longer than in 2014). Hospital psychiatric care was implemented in general hospitals at 142 psychiatric wards and 48 detoxification wards, where the total number of beds equaled 6,800 beds used by 86,400 patients $(0.9 \%$ less than in 2014) [11]. 


\section{The system of psychiatric care - organization and financing rules}

All guaranteed services involving psychiatric care and addiction treatment are granted to patients on the following conditions:

- Stationary: psychiatric, addiction treatment, emergency rooms;

- Daily: psychiatric, addiction treatment;

- Outpatient: psychiatric and community-based treatment (home-based), addiction treatment [12].

In the Polish system of psychiatric care, the payer's expenditures (the National Health Fund) are mainly intended to cover a hospital treatment. In $2015,70 \%$ of the costs of psychiatric treatment involved the treatment in stationary conditions (hospital), 24\% - in outpatient conditions and $6 \%$ constituted daily services [13].

\section{Social support for mentally impaired patients}

In a situation when a patient requires others' help due to his/her age, illness or disability and is a lonely person or his/her family (a spouse, ascendants and descendants) are not able to guarantee such help, he or she may benefit from care services provided in his/her place of residence. In the case of people with psychiatric disorders, there are specialist care services. They cover: satisfying of daily needs (tidying up, washing, shopping, meal preparation), hygienic care, a type of care recommended by a doctor and ensuring of a contact with the surrounding environment [14]. Specialist care services are funded from the state budget by a municipality. Their scope, period and place are determined by a municipal welfare center, which may independently realize the above mentioned services or assign them to other competent bodies [15]. Additionally, there are services in support centers and community self-help homes available for people suffering from mental disorders involving a day or 24-hour stay.

\section{Characteristics of the psychiatric health care centers}

Sometimes community-based support is not sufficient and there is no possibility of ensuring care in the most advantageous conditions for the healing process (home). It takes place in the following situations:

- The risk of health and life safety of a mentally ill person or his/her surroundings;

- When a patient is a lonely person and does not receive an appropriate support from his/her family, and requires absolute continuation of psychiatric treatment, care and rehabilitation, also due to the presence of considerable and permanent behavior disorders;

- People referred to the units of health protection on the basis of courts' decisions.

Moreover, some people with mental disorders are not able to function independently in the home environment in spite of the fact that they have been covered by various forms of community-based care. More and more frequently there appears a necessity to provide 24-hour care and assistance for people with mental disorders, what contributes to family, professional and social exclusion of people who take care of such patients. In the above mentioned situation, there is a possibility, or sometimes even necessity to use a long-term stationary (hospital-based) care - a psychiatric health care center. This relatively new form of the institutional healthcare was established in 1991. Within the meaning of the Act on Mental Health Protection, the psychiatric health care center is a psychiatric hospital, whereas in accordance with the Act on Medical Activity, it is not a hospital but other medical facility providing 24-hour psychiatric or detoxification care, irrespectively to a subject which creates and maintains it $[10,16]$. The psychiatric health care center admits people who do not require hospitalization but, due to their mental health status, need the continuation of psychiatric treatment. Moreover, they need permanent or temporary care, or are unable to independently satisfy their basic needs because of their family situation (incapability or unwillingness of family members to take care of a person), social situation (lack of family), or require psychiatric rehabilitation (occupational therapy) or systemic one (physiotherapeutic procedures). People with organic mental disorders, including syndrome complexes (F00-F09 acc.to ICD-10); schizophrenia, schizotypal and delusional disorders (F20-F29 acc.to ICD10); mood disorders (F30-F39 acc. to ICD-10) and mental handicap (F70-F79 acc.to ICD-10) are treated in the care and treatment centers [17]. Patients are admitted upon their own consent (also required in the case of an incapacitated person) or on the basis of the court's decision (article 38 and 39 of the Act on Mental Health Protection). The application for admission to the psychiatric care and treatment center shall be filled in by a physician having the contract signed up with the National Health Fund [18]. The information on the approximate waiting time to be admitted to the psychiatric care and treatment center can be found in the nationwide guide on waiting time for medical services (http://kolejki. nfz.gov.pl/). Out-of-turn admission, in accordance with the organizational capacity of a healthcare provider, is possible in the case of honoured voluntary blood donors, honoured transplant donors, war and military invalids, veterans and selected repressed persons $[19,20]$. In the psychiatric health care centers there are no doctors' duties but 24-hour nursing care is guaranteed. The minimum number of personnel, in individual occupational groups, is stipulated in the Decree No. 79/2013/DSOZ of the President of the National Health Fund of December 13th 2013, on the specification of terms and execution of contracts involving psychiatric care and addiction treatment [17], whereas for the nursing personnel - the Ordinance of the Ministry of Health of December 28th 2012 on the way of determining 
of minimum norms of nurses' and midwives' employment in the healthcare institutions not being entrepreneurs [21]. A significantly new solution introduced in some care and treatment centers is employing of medical carers.

It should be noted that the regulations of the Act on Mental Health Protection does not include the possibility to refer to the health care center. The consequence of the above is the fact that courts, not differentiating between the forms of institutional care, refer people with mental disorders to the nursing home instead of to the heath care center (a healthcare unit). The basic criterion of the admission to the health care center is health status, presence of an illness and necessity of continuation of treatment, while the reason of referral to the nursing home (also for chronically mentally ill patients) is and should be: vital incapability, lack of home support or homelessness. Both forms of the institutional care (health care center and nursing home) focus their activities on ensuring of decent social and living conditions.

It shall also be emphasized that treatment of mental disorders is the domain of medicine (psychiatry). The health care center provides 24-hour health services which involve, inter alia, care and rehabilitation of patients who do not require hospitalization; it provides medicinal products and medical devices; carries out health education for patients and members of their families; prepares for selfcare in the domestic environment $[16,17,20]$. The nursing home, on the other hand, offers services of general interest (accommodation, alimentation, clothes, footwear and cleanliness maintenance), care services (assistance in the basic life activities, hygiene and care, handling of personal affairs) and supportive services (among others, enabling of participation in occupational therapy, enhancement of fitness and activation, satisfying of religious and cultural needs, sustenance and development of the contact with family or local community $[14,22]$.

Patients showing exacerbated and prolonged autoaggressive and aggressive behaviours pose a serious problem for currently operating psychiatric health care centers and nursing homes. It is worth noting that not every aggressive behavior in a patient with a diagnosed mental disorder stems from his/her mental illness, and in such case, educational and psycho-corrective impact is more appropriate rather than typically medical (pharmacological) one. It frequently happens that patients with exacerbated and prolonged behavior disorders are referred to the care center on the basis of the court's decision because disorders of their behavior pose a threat to social safety and other people's health and/or life. The discussed problem often concerns the people with mental handicap, personality disorder or the patients in whom the above listed disorders constitute the component of double diagnosis. With the current level of knowledge and development, the modern psychiatry is not able to cure a mental handicap. No efficient methods of mental handicap and personality disorder treatment are known. The most frequently used methods include psychotherapeutic impacts, although their effectiveness is assessed at the level of $2-7.5 \%$ [23]. It shall be born in mind that in order for this therapy to be successful, a patient's absolute consent, acceptance and active participation are indispensable. Multidisciplinary influences (therapeutic, treatment, rehabilitation and social ones) that can be undertaken by the care center, frequently turn out to be insufficient, that is why this area definitely needs the systemic solutions. Perhaps it would be more reasonable to create a psychiatric hospital ward with the reinforced monitoring with the staff composed of more male employees (high degree of female employees doing medical jobs) and 24-hour availability of medical staff (for example, the possibility of continuation of the use of coercive measures), which would also enable to undertake socio-therapeutic, educational, correctional, re-educational and re-integrational activities.

\section{Inpatient long-term care in Poland - statistics}

Long-term care implemented in residential conditions plays an increasingly important role, particularly when it comes to the process of demographic ageing. Such units include care centers and nursing centers of both general and psychiatric profiles. In 2015 in Poland there were 560 facilities providing long-term care $(5.6 \%$ more than in 2014). As many as 59 of them constituted psychiatric centers with 5,700 places and 7,600 patients were admitted to them (5.6\% more than in 2014). In 2015 the structure of beds in stationary establishments of long-term healthcare had the following proportion: general care centers $-61.1 \%$, psychiatric care centers - $17.6 \%$, while general nursing homes constituted $20.8 \%$ and psychiatric ones $-0.4 \%$ [11].

\section{Summary}

Treatment in the psychiatric hospital should be a marginal element of the community-based psychiatric care, yet sometimes an indispensable one. A majority of patients with mental disorders do not require psychiatric hospitalization, that is why the degree of development of non-hospital forms of treatment including long-term care facilities is of crucial importance. With the ageing population and consequently, with an increasing number of people with mental disorders, one can expect a growing demand for the long-term care ensuring comprehensive and high quality care services. Thanks to the possibility of continuation of psychiatric treatment in the care center, the efficiency of the use of "emergency" hospital beds has been considerably improved by:

- Reduction of re-hospitalization in the case of the patients who, after the discharge from the psychiatric 
hospital due to various reasons, did not continue treatment in the outpatient conditions;

- Reduction of maximum length of psychiatric hospitalization from several or several dozens of years to several months (length of waiting time for a place in the care center).

The care center, being a healthcare unit providing health services, remains a cheaper (as compared to hospital) form of treatment of people with mental disorders, partly because of the fact that a patient bears the costs of accommodation and alimentation [20]. In the authors' opinion, the care center is an integral part of the Polish system of psychiatric care, similarly as the hospital complex is an integral part of the mental health center. It seems that the way in which patients have been referred to the care centers so far, is the evidence of insufficiency of the psychiatric care system as well as social support. There is a clear lack of other forms of care - community-based services (both care and treatment ones), which would constitute an alternative for a part of patients and would enable them to keep functioning in their own family environment and local community, also thanks to the active support including various forms of sheltered accommodation.

The protection of mental health has never been the priority in the health policy of our state. The introduction of numerous changes is absolutely necessary in the area of basic, specialist and hospital-based psychiatric care. Restructuring of large hospitals, reduction of the number of hospital beds, introduction of all-Poland therapeutic programs, for example of the treatment of schizophrenia, depressive states, prevention and treatment of civilization disorders, the program of sheltered flats, protected work, care and therapy of people over 60 and finally amendment of the Act on Mental Health Protection - all of these still pose a challenge for the state institutions and public officers in charge of the system of mental health protection. The authors of the paper positively assess the draft amendments presented by the Ministry of Health concerning the guaranteed services in the area of specialist psychiatric care in which the care center is one of the components providing health services focusing on the treatment of psychoses and geriatric psychiatry.

The Polish system of psychiatric care is characterized by considerably low effectiveness and sufficiency (particularly as compared to expectations), and its elements described above, disintegrated due to a number of managing bodies and ways of financing, do not create a coherent and target-oriented system. The lack of functional integration of medical and psycho-social services provided by various subjects poses a real obstacle for efficiency and distribution of the above mentioned services to patients suffering from mental disorders. In the modern system of care over mentally disabled people, it is essential that all these elements coexist and there are clear criteria set for individual healthcare services and standards of their performance.

\section{Conclusions}

1. Although the psychiatric care center is not a community-based facility, and concerns the marginal part of patients, it occupies a very significant place in the Polish system of psychiatric care.

2. From the perspective of a person with a mental disorder, the continuation of treatment in the care center, rather than in the nursing home for the chronically mentally ill, is more advantageous.

3. There is a need for a wider discussion of the role of individual elements of the system of psychiatric healthcare (the complex of community-based treatment, a daily ward, a hostel for people with mental disorders, a care center) and social assistance (specialist care services, a community self-help home, sheltered accommodation, a nursing home) as well as development of functional integration among them.

\section{Wstęp}

W Polsce, podobnie jak w innych krajach europejskich, obserwuje się stały wzrost liczby udzielanych świadczeń zdrowotnych w zakresie opieki psychiatrycznej i leczenia uzależnień. Wskazuje się na dwukrotny wzrost porad w ambulatoryjnej opiece zdrowotnej, a w lecznictwie stacjonarnym o 50\% [1]. Wiąże się to między innymi z pojawieniem się nowych wyzwań cywilizacyjnych: przemian kulturowych i socjo-ekonomicznych oraz związane z nimi zagrożenie marginalizacją, stosowanie substancji psychoaktywnych, starzenie się społeczeństw, migracja. Zaburzenia psychiczne stanowią istotny problem medyczny i społeczny. Prowadzą do dyskryminacji czy wykluczenia społecznego osób nimi dotkniętych.

Choroby psychiczne zajmują czwarte miejsce na liście przyczyn niepełnosprawności polskiej społeczności [2]. Przez wiele lat jedynym źródłem danych o rozpowszechnieniu zaburzeń psychicznych w Polsce były statystyki Instytutu Psychiatrii i Neurologii w Warszawie. W 2012 roku zrealizowano pierwsze, trzyletnie badanie epidemiologiczne dotyczące rozpowszechnienia chorób psychicznych i dostępności psychiatrycznej opieki zdrowotnej. Przeprowadzono je zgodnie z metodologią Światowej Organizacji Zdrowia (WHO) we współpracy z Konsorcjum World Mental Health (WMH). Badanie EZOP wykazało, że 23,4\% polskiej populacji (ponad sześć milionów osób) co najmniej raz w życiu doświadczyło jednego zaburzenia psychicznego. W tej grupie osób co czwarta doświadczyła więcej niż jednego, a co dwudziesta piąta - trzech i więcej zaburzeń psychicznych [3]. 


\section{Polski system opieki psychiatrycznej - rys historyczny}

Proces transformacji modelu opieki psychiatrycznej $\mathrm{z} \quad$ systemu instytucjonalnego (szpitalnego, najkosztowniejszego) do modelu opieki środowiskowej (spersonalizowanego, tańszego) trwa w Polsce od wielu lat. Już w pierwszej połowie XX wieku pojawiły się inspiracje omawianej reformy. W latach 50. minionego stulecia, na transformację opieki psychiatrycznej dodatkowo korzystnie wpłynął postęp w zakresie farmakoterapii zaburzeń psychicznych (wprowadzenie i upowszechnienie nowych, skutecznych neuroleptyków i leków przeciwdepresyjnych). W latach 70. XX wieku w Małopolsce zastosowano pierwsze rozwiązania skierowane na opiekę środowiskową (leczenie domowe). W latach 1970-1995 nastąpiły pozytywne dla procesu transformacji zmiany. Zmniejszyła się liczba łóżek psychiatrycznych, a zwiększyły się liczby: oddziałów psychiatrycznych przy szpitalach ogólnych i łóżek w tychże oddziałach; szpitali psychiatrycznych (tworzono nowe, mniejsze placówki), zwiększając ich dostępność; poradni i oddziałów dziennych. Wtedy też powstały pierwsze zespoły leczenia środowiskowego. W latach 80. XX wieku z powodu ograniczenia liczby łóżek szpitalnych i wzrostu popytu na psychiatryczne świadczenia zdrowotne, nasiliły się niekorzystne zjawiska: rehospitalizacja (system „drzwi obrotowych”), przedłużanie pobytu w szpitalu psychiatrycznym z przyczyn socjalnych i kierowanie chorych do domów pomocy społecznej (niewystarczających pod względem liczby i standardu) [4]. Zmiany ustawodawcze wprowadzone w latach 90. ubiegłego stulecia (między innymi ustawa o ochronie zdrowia psychicznego, o pomocy społecznej) umożliwiły dalsze zmiany systemu opieki nad osobami z zaburzeniami psychicznymi. W 2010 roku Rada Ministrów przyjęła Narodowy Program Ochrony Zdrowia Psychicznego, w którym określono kierunek rozwoju systemu opieki psychiatrycznej i leczenia uzależnień na rozwój form opieki środowiskowej [5]. Podstawową opiekę psychiatryczną mają zapewnić centra zdrowia psychicznego (CZP), składające się z czterech podjednostek - zespołu: poradni (poradnia zdrowia psychicznego, PZP), leczenia środowiskowego (ZLŚ), dziennego i szpitalnego.

\section{Polski system opieki psychiatrycznej - dynamika zmian}

Wiele osób z zaburzeniami psychicznymi nie korzysta z opieki zdrowotnej i nie ma możliwości skorzystania z niej. Ocenia się, że z pomocy psychiatrycznej w Polsce korzysta około $25 \%$ osób potrzebujących [6], podczas gdy pomocą psychiatryczną powinna zostać objęta populacja co najmniej 33-50\% osób z zespołem depresyjnym czy uzależnieniem i 80\% osób z zespołem otępiennym czy schizofrenią [7].

Osoba z zaburzeniem psychicznym, samodzielnie

Rycina 1. Schemat polskiego systemu opieki psychiatrycznej.

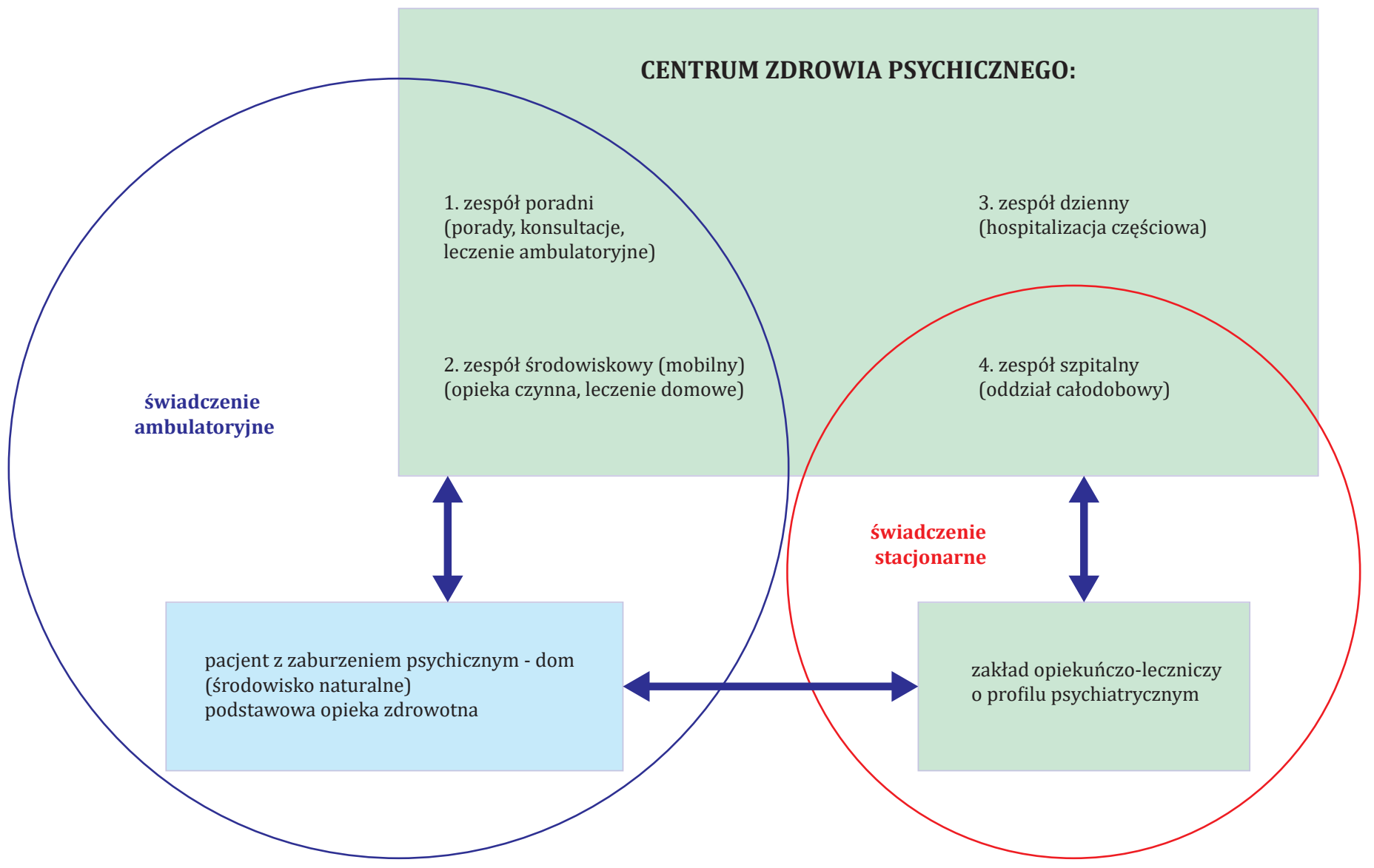


bądź ze wsparciem rodziny, może i powinna funkcjonować w środowisku domowym, będąc pod opieką środowiskowych form leczenia i wsparcia społecznego. Efektywny skoordynowany system opieki środowiskowej powinien znacząco poprawiać współpracę w leczeniu, a środowiskowe formy leczenia (PZP, ZLŚ, oddział dzienny i hostel dla osób z zaburzeniami psychicznymi) mają zapewnić pełną dostępność, ciągłość i kompleksowość opieki. Liczba osób z zaburzeniami psychicznymi korzystająca z opieki ambulatoryjnej $\mathrm{w}$ okresie ostatnich czterech lat wzrosła o 150000 osób (wzrost o 14\%). Największy wzrost odnotowano $\mathrm{w}$ opiece środowiskowej (zespoły leczenia środowiskowego), gdzie ogólna liczba leczonych zwiększyła się trzykrotnie (z9600 do 29800). Nadal najpowszechniejszą formą psychiatrycznej opieki ambulatoryjnej, dostępną w 93\% powiatów naszego kraju, jest poradnia zdrowia psychicznego. W 2011 roku funkcjonowało 68 zespołów leczenia środowiskowego, głównie w dużych ośrodkach miejskich. Leczenie w psychiatrycznym oddziale dziennym jest szansą na uniknięcie hospitalizacji psychiatrycznej, bądź stanowi jej uzupełnienie. W psychiatrycznej opiece dziennej w 2014 roku leczyło się 16000 osób (o 9\% więcej niż w 2011 roku) [8]. Hostel, prowadzący profilowane programy psychoterapeutyczne i rehabilitacyjne, w warunkach chronionego, zbliżonego do domowego zakwaterowania, jest w Polsce najmniej dostępną formą opieki psychiatrycznej. Na terenie siedmiu województw, w roku 2011 roku funkcjonowało 19 hosteli, do których trafiło 649 osób (w większości osób uzależnionych) [9].

Czasami leczenie w warunkach ambulatoryjnych jest bardzo trudne a nawet niemożliwe np. ze względu na stopień nasilenia objawów chorobowych, szczególnie $\mathrm{w}$ sytuacji agresji, autoagresji czy $\mathrm{z}$ powodu braku współpracy pacjenta i/lub jego rodziny $\mathrm{w}$ procesie terapeutycznym. Wówczas pacjent może być poddany hospitalizacji psychiatrycznej (za zgodą własną, w trybie nagłym bądź wnioskowym - art. 22, 23 i 29 ustawy o ochronie zdrowia psychicznego, UOZP) [10]. Pobyt w szpitalu, z różnych względów (terapeutycznych - niedługi pobyt poza środowiskiem domowym, ekonomicznych - najdroższa forma leczenia) powinien trwać możliwie jak najkrócej. W2015 roku natereniekrajubyło48szpitali psychiatrycznych (w 2014 roku - 49), które dysponowały łącznie 17800 łóżkami (o 0,2\% więcej niż w 2014 roku). Przebywało w nich 200800 pacjentów (o 0,4\% mniej niż w 2014 roku). Średni pobyt chorego w szpitalu psychiatrycznym wynosił 30,1 dnia (dłuższy niż w 2014 roku). Szpitalna opieka psychiatryczna była realizowana w szpitalach ogólnych na 142 oddziałach psychiatrycznych i 48 oddziałach odwykowych, gdzie łączna ilość łóżek wyniosła 6800 łóżek, z których skorzystało 86400 pacjentów (o $0,9 \%$ mniej niż w 2014 roku) [11].

\section{System opieki psychiatrycznej - zasady organizacji} i finansowania

Świadczenia gwarantowane w zakresie opieki psychiatrycznej i leczenia uzależnień udzielane są pacjentom w warunkach:

- stacjonarnych: psychiatrycznych, leczenia uzależnień, izby przyjęć;

- dziennych: psychiatrycznych, leczenia uzależnień;

- ambulatoryjnych: psychiatrycznych i leczenia środowiskowego (domowego), leczenia uzależnień [12].

W polskim systemie opieki psychiatrycznej wydatki płatnika (Narodowy Fundusz Zdrowia, NFZ) przeznaczane są głównie na leczenie szpitalne. W 2015 roku 70\% kosztów leczenia psychiatrycznego stanowiło leczenie w warunkach stacjonarnych, $24 \%$ - w warunkach ambulatoryjnych, a $6 \%$ - to świadczenia dzienne [13].

\section{Oparcie społeczne dla osób z zaburzeniami psychicznymi}

W sytuacji, kiedy pacjent wymaga pomocy innych z powodu: wieku, choroby lub niepełnosprawności oraz jest osobą samotną lub jego rodzina (małżonek, wstępni i zstępni) nie są w stanie takiej pomocy zapewnić, może skorzystać z usług opiekuńczych realizowanych w jego miejscu zamieszkania. W przypadku osób z zaburzeniami psychicznymi są to specjalistyczne usługi opiekuńcze. Usługi te obejmują: zaspokajanie codziennych potrzeb życiowych (sprzątanie, pranie, zakupy, sporządzanie posiłków), opiekę higieniczną, zaleconą przez lekarza pielęgnację, zapewnianie kontaktów z otoczeniem [14]. Specjalistyczne usługi opiekuńcze są finansowane z budżetu państwa, za pośrednictwem gminy. Ich zakres, okres i miejsce świadczenia usług określa ośrodek pomocy społecznej, który może samodzielnie realizować powyższe usługi lub zlecać je innym uprawnionym podmiotom [15]. Dodatkowo dla osób z zaburzeniami psychicznymi dostępne są usługi w ośrodkach wsparcia i środowiskowym domu samopomocy (ŚDS), w ramach dziennego lub całodobowego pobytu.

\section{Charakterystyka psychiatrycznego zakładu opiekuńczo-leczniczego}

Czasami wsparcie środowiskowe jest niewystarczające i nie ma możliwości zapewnienia pacjentowi opieki w warunkach najkorzystniejszych dla procesu zdrowienia (dom). Ma to miejsce w sytuacji:

- zagrożenia bezpieczeństwa zdrowia i życia osoby chorej psychicznie lub jej otoczenia;

- kiedy pacjent jest osobą samotną i/lub nie znajduje odpowiedniego wsparcia w środowisku rodzinnym, a wymaga bezwzględnej kontynuacji leczenia psychiatrycznego, opieki, pielęgnacji i rehabilitacji, także ze względu na obecność znacznych i utrwalonych zaburzeń 
zachowania;

- osób kierowanych do jednostek ochrony zdrowia (ZOL) na mocy postanowienia sądu. Ponadto część osób z zaburzeniami psychicznymi, pomimo objęcia różnymi formami opieki środowiskowej nie jest w stanie samodzielnie utrzymać się w środowisku domowym. Coraz częściej istnieje konieczność sprawowania całodobowej opieki i pomocy osobom z zaburzeniami psychicznymi, co przyczynia się do wykluczenia rodzinnego, zawodowego i społecznego osób zajmujących się nimi. W powyższych sytuacjach istnieje możliwość, a czasem konieczność korzystania z opieki stacjonarnej, długoterminowej - psychiatrycznego zakładu opiekuńczo-leczniczego (ZOL). Ta stosunkowo nowa forma instytucjonalnej opieki zdrowotnej powstała w 1991 roku. W rozumieniu ustawy o ochronie zdrowia psychicznego ZOL jest szpitalem psychiatrycznym, natomiast zgodnie $\mathrm{z}$ ustawą o działalności leczniczej nie jest szpitalem, ale innym zakładem leczniczym, sprawującym całodobową opiekę psychiatryczną lub odwykową, niezależnie od podmiotu, który go tworzy i utrzymuje $[10,16]$.

Do psychiatrycznego ZOL-u przyjmowane są osoby, które nie wymagają hospitalizacji, ale ze względu na stan zdrowia psychicznego wymagają kontynuacji leczenia psychiatrycznego. Ponadto potrzebują stałej lub czasowej opieki i pomocy; bądź są niezdolne do samodzielnego zaspokajania podstawowych potrzeb życiowych, ze względu na sytuację rodzinną (niemożność lub niechęć rodziny, osób najbliższych do sprawowania opieki nad członkiem swojej rodziny), społeczną (brak rodziny); wymagają rehabilitacji psychiatrycznej (terapia zajęciowa) i ogólnoustrojowej (zabiegi fizjoterapeutyczne). W ZOL-u leczone są osoby z powodu: organicznych zaburzeń psychicznych, włącznie z zespołami objawowymi (F00-F09 wg ICD-10); schizofrenii, zaburzeń typu schizofrenii (schizotypowego) i urojeniowego (F20-F29 wg ICD-10); zaburzeń nastroju (F30-F39 wg ICD-10) oraz upośledzenia umysłowego (F70-F79 wg ICD-10) [17]. Pacjenci przyjmowani są za zgodą: własną (wymaganą także w przypadku osoby ubezwłasnowolnionej) lub na mocy postanowienia sądu (art. 38 i 39 UOZP). Wniosek o przyjęcie do psychiatrycznego ZOL-u wypełnia lekarz ubezpieczenia zdrowotnego [18]. Informację o przybliżonym czasie oczekiwania na przyjęcie do ZOL-u można znaleźć w ogólnopolskim informatorze o czasie oczekiwania na świadczenia medyczne (http://kolejki.nfz.gov.pl/). Przyjęcie poza kolejnością, zgodniezmożliwościamiorganizacyjnymiświadczeniodawcy, możliwe jest w przypadku: zasłużonych honorowych dawców krwi, zasłużonych dawców przeszczepu, inwalidów wojennych i wojskowych, kombatantów oraz niektórych osób represjonowanych [19,20]. W ZOL-u psychiatrycznym nie ma dyżurów lekarskich, ale zapewniona jest całodobowa opieka pielęgniarska. Minimalną liczbę personelu, w poszczególnych grupach zawodowych, określa
Zarządzenie Nr 79/2013/DSOZ Prezesa Narodowego Funduszu Zdrowia z dnia 13 grudnia 2013 roku w sprawie określenia warunków zawierania i realizacji umów w rodzaju opieka psychiatryczna i leczenie uzależnień [17], natomiast dla personelu pielęgniarskiego - Rozporządzenie Ministra Zdrowia z dnia 28 grudnia 2012 roku w sprawie sposobu ustalania minimalnych norm zatrudnienia pielęgniarek i położnych w podmiotach leczniczych niebędących przedsiębiorcami [21]. Nowością w strukturze zatrudnienia niektórych ZOL-i jest zatrudnianie opiekunów medycznych.

Należy nadmienić, że zapisy UOZP nie uwzględniają możliwości skierowania do ZOL. Konsekwencją tego jest fakt, że sądy nie rozróżniając form opieki instytucjonalnej, kierują osoby z zaburzeniami psychicznymi do jednostki pomocy społecznej tj. domu pomocy społecznej (DPS), zamiast do ZOL-u (jednostka ochrony zdrowia). Podstawowym kryterium przyjęcia do ZOL-u jest stan zdrowia, obecność choroby i konieczność kontynuacji leczenia, natomiast przyczyną kierowania do DPS-u (także dla przewlekle psychicznie chorych), jest i powinny być: nieporadność życiowa, brak wsparcia środowiska domowego czy bezdomność. Obydwie formy opieki instytucjonalnej (i ZOL, i DPS) ogniskują swoje działania na zapewnieniu godnych warunków socjalno-bytowych.

Należy zaznaczyć, że leczenie zaburzeń psychicznych jest domeną medycyny (psychiatrii). ZOL udziela całodobowych świadczeń zdrowotnych, które obejmują między innymi pielęgnację i rehabilitację pacjentów niewymagających hospitalizacji; zapewnia produkty lecznicze i wyroby medyczne; prowadzi edukację zdrowotną dla pacjentów i członków ich rodzin; przygotowuje do samoopieki i samopielęgnacji w warunkach domowych $[16,17,20]$. Natomiast DPS oferuje usługi bytowe (miejsce zamieszkania, wyżywienie, odzież i obuwie, utrzymanie czystości), opiekuńcze (pomoc w podstawowych czynnościach życiowych, pielęgnacji, załatwianiu spraw osobistych) i wspomagające (między innymi umożliwienie udziału w terapii zajęciowej, podnoszenie sprawności i aktywizacji, zaspokajanie potrzeb religijnych i kulturalnych, utrzymywanie i rozwój kontaktu z rodziną czy lokalną społecznością) [14,22].

Poważnym problemem aktualnie funkcjonujących ZOL-i o profilu psychiatrycznym (podobnie jak DPS-ów dla przewlekle psychicznie chorych) są pacjenci z nasilonymi i utrwalonymi zachowaniami autoagresywnymi oraz agresywnymi. Warto zaznaczyć, że nie każde zachowanie agresywnie $u$ osoby $\mathrm{z}$ rozpoznanym zaburzeniem psychicznym wynika $\mathrm{z}$ choroby psychicznej i w takim przypadku bardziej uzasadnione jest oddziaływanie pedagogiczne i psychokorekcyjne niż typowo medyczne (farmakologiczne). Często chorzy z nasilonymi i utrwalonymi zaburzeniami zachowania kierowani są do ZOL-u na mocy postanowienia sądu, ponieważ zaburzenia 
ich zachowania stanowią zagrożenie bezpieczeństwa społecznego, zdrowia i/lub życia innych osób. Omawiany problem często dotyczy osób z upośledzeniem umysłowym, zaburzeniem osobowości bądź pacjentów, u których powyższe zaburzenia są składową podwójnej diagnozy. Współczesny poziom wiedzy i rozwoju psychiatrii nie daje możliwości wyleczenia upośledzenia umysłowego. Nieznane są też skuteczne metody leczenia upośledzenia umysłowego i zaburzenia osobowości. Najczęściej stosowane są oddziaływania psychoterapeutyczne, choć ich skuteczność ocenia się na 2-7,5\% [23]. Należy pamiętać, że aby psychoterapia była skuteczna, oddziaływania te wymagają bezwzględnej zgody, akceptacji i czynnego uczestnictwa osoby poddawanej takim działaniom. Wielodyscyplinarne oddziaływania (terapeutyczne, lecznicze, rehabilitacyjne, społeczne) możliwe do podjęcia w ramach ZOL-u, okazują się nieskuteczne, dlatego też $\mathrm{w}$ tym zakresie potrzebne są rozwiązania systemowe. Być może rozwiązaniem byłoby utworzenie oddziału o wzmocnionym nadzorze, w ramach szpitala psychiatrycznego, $\mathrm{z}$ większą liczbą personelu płci męskiej (wysoki współczynnik sfeminizowania pracowników wykonujących zawody medyczne) i całodobową dostępnością personelu lekarskiego (np. możliwość kontynuacji stosowania środków przymusu bezpośredniego), co umożliwiłoby także podejmowanie oddziaływań socjoterapeutycznych, pedagogicznych, resocjalizacyjnych, reedukacyjnych czy reintegracyjnych.

\section{Stacjonarna opieka długoterminowa w Polsce - statystyka}

Opieka długoterminowa realizowana w warunkach stacjonarnych odgrywa coraz ważniejszą rolę także wobec procesu starzenia się społeczeństwa. Do jednostek tego typu zalicza się zakłady opiekuńczo-lecznicze i pielęgnacyjno-opiekuńcze, zarówno o profilu ogólnym, jak i psychiatrycznym. W 2015 roku w Polsce było 560 zakładów udzielających świadczeń opieki długoterminowej (o 3,1\% więcej niż w 2014 roku). 59 z nich, były to zakłady o profilu psychiatrycznym, które dysponowały 5700 miejscami, do których przyjęto 7600 pacjentów (o 5,6\% więcej niż w 2014 roku). W 2015 roku struktura łóżek w stacjonarnych zakładach opieki długoterminowej opieki zdrowotnej rozkładała się w proporcji: zakłady opiekuńczo-lecznicze ogólne - 61,1 \%, tożsame o profilu psychiatrycznym $17,6 \%$, podczas gdy zakłady pielęgnacyjno-opiekuńcze ogólne stanowiły 20,8\% a psychiatryczne - 0,4\% [11].

\section{Podsumowanie}

Leczenie w szpitalu psychiatrycznym powinno być marginalnym elementem środowiskowej opieki psychiatrycznej, choć czasami niezbędnym. Większość osób z zaburzeniami psychicznymi nie wymaga hospitalizacji psychiatrycznej, dlatego istotne znaczenie ma stopień rozwoju pozaszpitalnych form leczenia, w tym także placówek opieki długoterminowej. Wraz ze starzeniem się populacji, a więc także osób z zaburzeniami psychicznymi, należy spodziewać się rosnącego zapotrzebowania na opiekę długoterminową, zapewniającą wszechstronną opiekę na możliwie najwyższym poziomie. Dzięki możliwości kontynuacji leczenia psychiatrycznego w ZOL-u poprawiła się efektywność wykorzystania „ostrych” łóżek szpitalnych, między innymi poprzez:

- zmniejszenie rehospitalizacji w przypadku pacjentów, którzy po wypisie ze szpitala psychiatrycznego z różnych względów nie kontynuowali leczenia w warunkach ambulatoryjnych;

- skrócenie maksymalnej długości hospitalizacji psychiatrycznej - z kilkunastu czy kilkudziesięciu lat do kilkunastu miesięcy (długość czasu oczekiwania na miejsce w ZOL-u).

ZOL, będąc jednostką ochrony zdrowia, udzielającą całodobowych świadczeń zdrowotnych, jest tańszą (w porównaniu do szpitalnej) formą leczenia osób z zaburzeniami psychicznymi, między innymi dlatego, że pacjent ponosi koszty zakwaterowania i wyżywienia [20]. Zdaniem autorów ZOL o profilu psychiatrycznym jest integralną częścią polskiego systemu opieki psychiatrycznej, podobnie jak zespół szpitalny jest integralną częścią centrum zdrowia psychicznego. Wydaje się, że dotychczasowa praktyka kierowania do ZOL-u, w pewnym stopniu dowodzi niewydolności systemu opieki psychiatrycznej i oparcia społecznego. Brakuje innych form opieki - świadczeń środowiskowych (i leczniczych, i opiekuńczych), które dla części pacjentów zakładu tego typu byłyby alternatywą i pozwoliłyby na dalsze funkcjonowanie we własnym środowisku rodzinnym i społeczności lokalnej, także dzięki aktywnemu wsparciu w postaci różnych form zamieszkiwania chronionego.

Ochrona zdrowia psychicznego nigdy nie była priorytetem $\mathrm{w}$ polityce zdrowotnej naszego Państwa. Niezbędne są zmiany w zakresie podstawowej, specjalistycznej i stacjonarnej opieki psychiatrycznej. Restrukturyzacja dużych szpitali psychiatrycznych, zmniejszenie ilości łóżek szpitalnych, wprowadzenie ogólnopolskich programów terapeutycznych np. leczenia schizofrenii, stanów depresyjnych, profilaktyki i leczenia zaburzeń cywilizacyjnych, program mieszkań chronionych, pracy chronionej w obrębie placówek psychiatrycznych czy opieki i terapii nad osobami powyżej 60 roku życia a także nowelizacja UOZP - nadal są wyzwaniem dla instytucji Państwai osóbodpowiedzialnych za funkcjonowanie systemu ochrony zdrowia psychicznego. Autorzy pracy pozytywnie oceniają projekt zmian przedstawiony przez Ministerstwo Zdrowia w zakresie świadczeń gwarantowanych w ramach specjalistycznej opieki psychiatrycznej, w którym zakład opiekuńczo-leczniczy jest jedną z jednostek składowych 
udzielających świadczeń zdrowotnych w zakresie leczenia psychoz i psychogeriatrii.

Polski system opieki psychiatrycznej cechuje stosunkowo niska (w stosunku do oczekiwań) skuteczność i sprawność, a opisane wyżej jego elementy, zdezintegrowane ze względu na mnogość podmiotów zarządzających oraz sposób finansowania, nie tworzą spójnego, nastawionego na jeden cel systemu. Brak funkcjonalnej integracji świadczeń medycznych i psychospołecznych, udzielanych przez różne podmioty stanowią barierę dla efektywności i dystrybucji wyżej wymienionych świadczeń dla osób z zaburzeniami psychicznymi. W nowoczesnym systemie opieki nad osobami z zaburzeniami psychicznymi niezbędne jest współistnienie wszystkich wyżej wymienionych elementów, przy założeniu funkcjonowania jasnych kryteriów korzystania z poszczególnych świadczeń oraz standardów ich wykonywania.

\section{Wnioski}

1. ZOL o profilu psychiatrycznym, choć nie jest placówką środowiskową i dotyczy marginalnej części pacjentów, zajmuje ważne miejsce w polskim systemie psychiatrycznej opieki zdrowotnej.

2. Z perspektywy osoby z zaburzeniem psychicznym korzystniejsza jest kontynuacja leczenia w warunkach ZOL-u o profilu psychiatrycznym niż w DPS-ie dla przewlekle psychicznie chorych.

3. Istnieje potrzeba szerokiej dyskusji nad rolą poszczególnych elementów sytemu psychiatrycznej opieki zdrowotnej (zespół leczenia środowiskowego, oddział dzienny, hostel dla osób z zaburzeniami psychicznymi, zakład opiekuńczo-leczniczy) i pomocy społecznej (specjalistyczne usługi opiekuńcze, środowiskowy dom samopomocy, mieszkanie chronione, dom pomocy społecznej) i wypracowanie funkcjonalnej integracji pomiędzy nimi.

\section{Conflict of interest}

The authors have declared no conflict of interest.

\section{References:}

1. Mazur I, Karnieja P, Jończyk J. Zdrowie psychiczne. Organizacja Zarządzanie - Standardy. Wrocław: 2015.

2. A. Denys. Zagrożenia Zdrowia Publicznego. Wybrane zagadnienia, ABC Wolters Kluwer, Warszawa: 2014.

3. Kiejna A, Adamowski T, Piotrowski P, Moskalewicz J, Wojtyniak B, Świątkiewicz G et al. Epidemiology of mental disorders and access to mental health care. EZOP - Poland" - research methodology Psychiatria Pol. 2015; 49(1):5-13.

4. Załuska M. The community-based psychiatric care model and changes in the health system structure in recent years in Poland. Postępy psychiatrii i Neurologii 2006;15(4):277-285.

5. Rozporządzenie Rady Ministrów z dnia 28 grudnia 2010 r. w sprawie Narodowego Programu Ochrony Zdrowia Psychicznego; Dz.U. 2011 nr 24 poz. 128.
6. Szafrański T. Ochrona zdrowia psychicznego we współczesnym świecie. W: Ochrona zdrowia psychicznego w Polsce: wyzwania, plany, bariery, dobre praktyki. Raport RPO. Warszawa: 2014.

7. Straathdee G, Thornicroft G. Community psychiatry and service evaluation. W: Murray R, Hill P, McGuffin P. The Essentials of Postgraduate Psychiatry, 3rd Edition. Cambridge University Press: 1997.

8. Rozporządzenie Rady Ministrów z dnia 8 lutego 2017 r. w sprawie Narodowego Programu Ochrony Zdrowia Psychicznego na lata 2017-2022; Dz.U. 2017 poz. 458.

9. Langiewicz W. System lecznictwa psychiatrycznego. W: Ochrona zdrowia psychicznego w Polsce: wyzwania, plany, bariery, dobre praktyki. Raport RPO. Warszawa: 2014.

10. Ustawa z dnia 19 sierpnia 1994r. o ochronie zdrowia psychicznego; Dz.U. 2016 poz.546.

11. Rocznik Statystyczny Rzeczypospolitej Polskiej 2015.

12. Rozporządzenie Ministra Zdrowia z dnia 6 listopada 2013 r. w sprawie świadczeń gwarantowanych z zakresu opieki psychiatrycznej i leczenia uzależnień; Dz.U. 2013 poz. 1386.

13. Łoza B, Gryglewicz J. Raport Narodowy Program Ochrony Zdrowia Psychicznego 2016-2020 - Rekomendacje. Warszawa: 2015.

14. Ustawa z dnia 12 marca 2004 r. o pomocy społecznej; Dz.U. 2016 poz.930.

15. Rozporządzenia Ministra Polityki Społecznej z dnia 22 września 2005 r. w sprawie specjalistycznych usług opiekuńczych; Dz.U. 2005 nr 189 poz. 1598.

16. Ustawa z dnia 15 kwietnia 2011 r. o działalności leczniczej; Dz.U. 2016 poz. 1638.

17. Zarządzenie Nr 79/2013/DSOZ Prezesa Narodowego Funduszu Zdrowia z dnia 13 grudnia 2013 r. w sprawie określenia warunków zawierania i realizacji umów w rodzaju opieka psychiatryczna i leczenie uzależnień.; Dz.U. z 2008 r. nr 164, poz.1027.

18. Rozporządzenie Ministra Zdrowia z dnia 25 czerwca 2012 r. w sprawie kierowania do zakładów opiekuńczo-leczniczych i pielęgnacyjno-opiekuńczych; Dz.U.2012 poz. 731.

19. Ustawa z dnia 24 stycznia 1991 r. o kombatantach oraz niektórych osobach będących ofiarami represji wojennych i okresu powojennego; Dz.U. 2016 poz. 1255.

20. Ustawa $\mathrm{z}$ dnia 27 sierpnia 2004 r. o świadczeniach opieki zdrowotnej finansowanych ze środków publicznych; Dz.U. 2016 poz. 1793.

21. Rozporządzenie Ministra Zdrowia z dnia 28 grudnia 2012 r. w sprawie sposobu ustalania minimalnych norm zatrudnienia pielęgniarek i położnych w podmiotach leczniczych niebędących przedsiębiorcami; Dz.U. z 2012 poz. 1545.

22. Rozporządzenie Ministra Pracy i Polityki Społecznej z dnia 23 sierpnia 2012 r. w sprawie domów pomocy społecznej; Dz.U. 2012 poz. 964.

23. Jakubik A. Zaburzenia osobowości. PZWL, Warszawa: 1997.

\section{Corresponding author:}

Aneta Tylec

II Klinika Psychiatrii i Rehabilitacji Psychiatrycznej,

ul. Głuska 1 20-439 Lublin

anetatylec@wp.pl

Otrzymano: 16.11 .2017

Zrecenzowano: 11.01.2018

Przyjęto do druku: 06.03.2018 